\title{
Contrasting recipes for the kiln furnitures of the faience manufacture Granges-le-Bourg (Haute Saône, France)
}

\author{
Marino MAGGETTI ${ }^{1}$, Denis MORIN², Vincent SERNEELS ${ }^{3}$ \\ Christoph NEURURER ${ }^{4}$
}

${ }^{1}$ Department of Geosciences, University, Fribourg, CH-1700, Switzerland

${ }^{2}$ CNRS, UMR 5608, TRACES, University, Toulouse, F-31000, France

${ }^{3}$ Department of Geosciences, University, Fribourg, CH-1700, Switzerland

${ }^{4}$ Department of Geosciences, University, Fribourg, CH-1700, Switzerland

Received February 2009; accepted June 2009

Available online September 2009

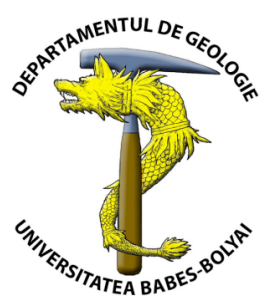

ABSTRACT. Thirty-nine samples of kiln furniture or technical ceramic (firing plate, saggars, spacers, props, wads) and six samples of building ceramics (bricks, tiles) from the manufacture of Granges-le-Bourg were studied by optical microscopy, X-ray fluorescence, $\mathrm{X}$-ray diffraction and scanning electron microscopy. The kiln furniture is chemically inhomogeneous and belong to a $\mathrm{CaO}-+\mathrm{MgO}$-poor (firing plate, saggars) or a $\mathrm{CaO}-+\mathrm{MgO}-\mathrm{rich}$ (props, spacers, wads) group. Bricks and tiles pertain to the first group, which was manufactured using decarbonatized top layers of local Triassic dolomitic marls. For the second group, the deeper layers were used. Plate and saggars are covered with a tin oxide opacified glassy coating with no significant reaction zone to the body.

Key words: Granges-le-Bourg, kiln furniture, high-Mg faience, Triassic marl, dolomite.

\section{INTRODUCTION}

During archaeological excavations of the brickworks $\left(16^{\text {th }}-19^{\text {th }}\right.$ c.) from Granges-le-Bourg, faience waste was found from an unknown late $18^{\text {th }} /$ early $19^{\text {th }} \mathrm{c}$. production (Morin and Morin-Hamon, 2004). In Granges-le-Bourg, coarse, as well as fine ceramic was therefore produced simultaneously. Results of the archaeometric analyses of the fine ware, i.e. the faience, and seven local clays have already been discussed (Maggetti et al., 2009). This study focus on 39 samples of kiln furniture or technical ceramic (firing plate, saggars, spacers, props, wads) and six samples of building ceramic (bricks, tiles) in order to answer the following questions: (1) Are there chemical differences between the technical, the building and the fine ceramics? (2) Did the potters use specific refractory clays and different recipes for the various ceramic types? (3) Are the raw materials of local or foreign (imported) origin?

Analytical techniques were optical microscopy, X-ray fluorescence (XRF), X-ray diffraction (XRD) and scanning electron microscopy (SEM), coupled to an energy-dispersive X-ray spectrometer (EDS). For analytical details see Maggetti et al. (2009).

\section{TERMINOLOGY}

Firing plates are also called shelves. Saggars are ceramic containers in which the tin-glazed earthenware is fired.
Spacers or pegs support the pottery in the saggars while the columnar props support the firing plates. Wads have varying forms as their main function is to insulate the saggars from the fire, to separate and to stabilize the vessels in the kiln.

\section{OPTICAL MICROSCOPY}

Under the polarizing microscope, faiences, props, spacers and wads show fine-grained bodies with tiny quartzes (maximum diameter up to $140 \mu \mathrm{m}$ ) and Feconcretions as non plastic inclusions (Fig. 1). The matrix of the firing plate and of the saggars doesn't differ, but both types contain well-rounded and well-sorted coarse grains of chert, microcline and mono/polycrystalline quartz (diameter 1 to $1.5 \mathrm{~mm}$, Fig. 2), resulting in a hiatal distribution of the non plastic inclusions (Maggetti, 1994).

\section{CHEMICAL COMPOSITION}

Many samples show unusually high lead concentrations (Table 1). The causes of this Pb-contamination were discussed by Maggetti et al. (2009). The kiln furnitures have different chemical compositions, as evidenced by the XRF analyses. The firing plate, the saggars and the building ceramics are - with the exception of GLB 6 - calcium- and magnesium-poor (Fig. 3), well suited to support high firing temperatures as well as several firing cycles. Contrasting, 
props, spacers and wads show markedly higher $\mathrm{CaO}$ and $\mathrm{MgO}$. This is corroborated by a principal component analysis (PCA) considering together major, minor and trace elements of the faiences, the clays and the kiln furnitures. Three distinct groups can be recognized (Fig. 4): (1) Bricks, firing plate, saggars and tiles; (2) Props, spacers and wads; (3) Faiences. Ca- and Mg-poor clays have comparable chemical compositions as the props. Three very $\mathrm{Ca}+\mathrm{Mg}$-rich clays are set apart.

It is interesting to note that one clay as well as some props and all spacers match the chemical composition of the faiences for mostly all oxides.
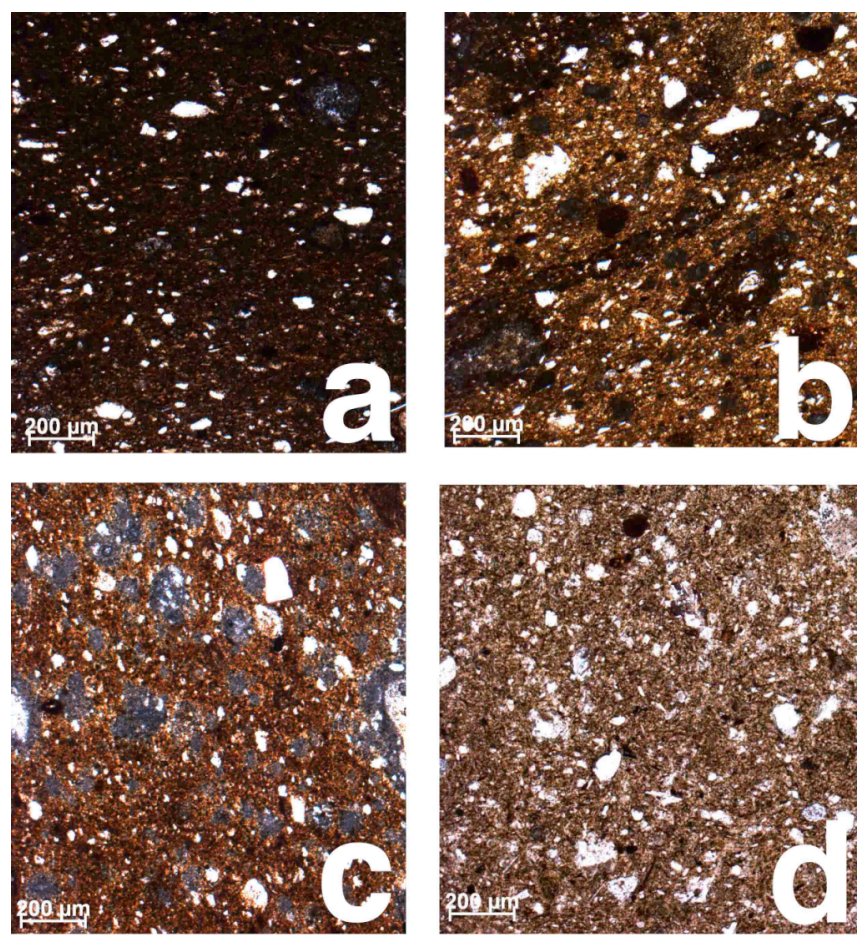

Fig. 1. Microphotographs of thin sections of a faience (a; GLB 28), a prop (b; GLB 99), a spacer (c; GLB 32) and a wad (d; GLB 51). Parallel polarizers.

\section{RAW MATERIALS}

The brick \& tile and faience works of Granges-le-Bourg are located on dolomitic, gypsiferous marls of the Triassic Middle Muschelkalk (Middle Anisian), see Contini (2000) and Contini et al. (2000). As shown by XRD, these clays are rich in dolomite (up to 50 wt. \%). In profiles, both $\mathrm{MgO}$ and $\mathrm{CaO}$ decrease from deeper layers upward, the concentrations of these two oxydes being very low close to the surface. Such features indicate progressive leaching of the mineral dolomite. Red Triassic sandstones (Buntsandstein) crop out close to the manufacture and were used for the construction of the kilns. These sandstones show rounded quartzes. By decaying, very pure quartz sands are generated.

\section{GLAZES}

The firing plate and some saggars are internally coated with a tin opacified lead glaze, which is markedly thinner and richer in splintery quartzes than the corresponding glaze of the faiences. Area measurements $(60 \times 50 \mu \mathrm{m})$ by SEM EDS showed a mean $\mathrm{SnO}_{2}$ content of $9.1 \mathrm{wt}$. \% for the faiences and $5.2 \mathrm{wt}$ \% for the kiln furnitures. No reaction zone between the body and the glaze could be observed.
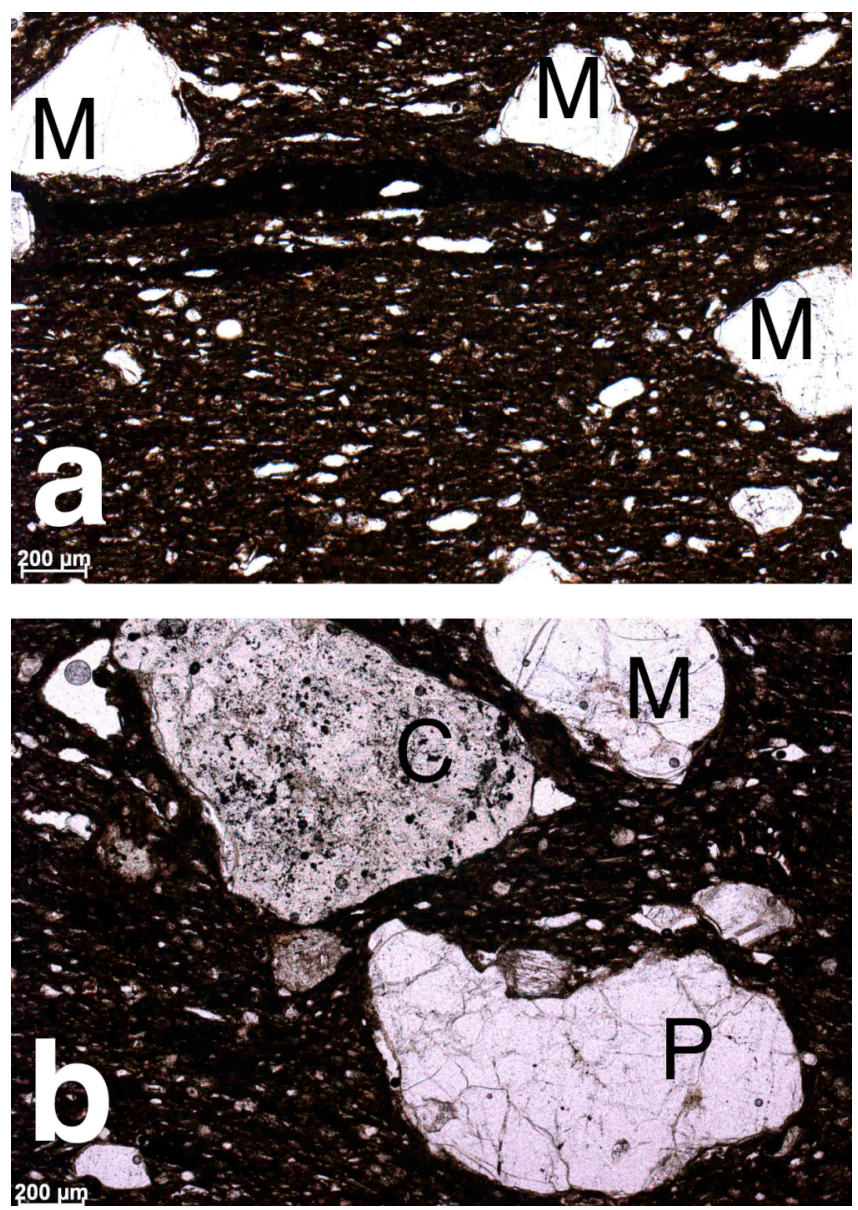

Fig. 2. Microphotographs of thin sections of a firing plate (a; GLB 107) and a saggar (b; GLB 91), showing rounded grains of chert $(C)$ and mono- $(M)$ as well as polycrystalline $(P)$ quartzes in a fine grained, non-calcareous matrix. Parallel polarizers.

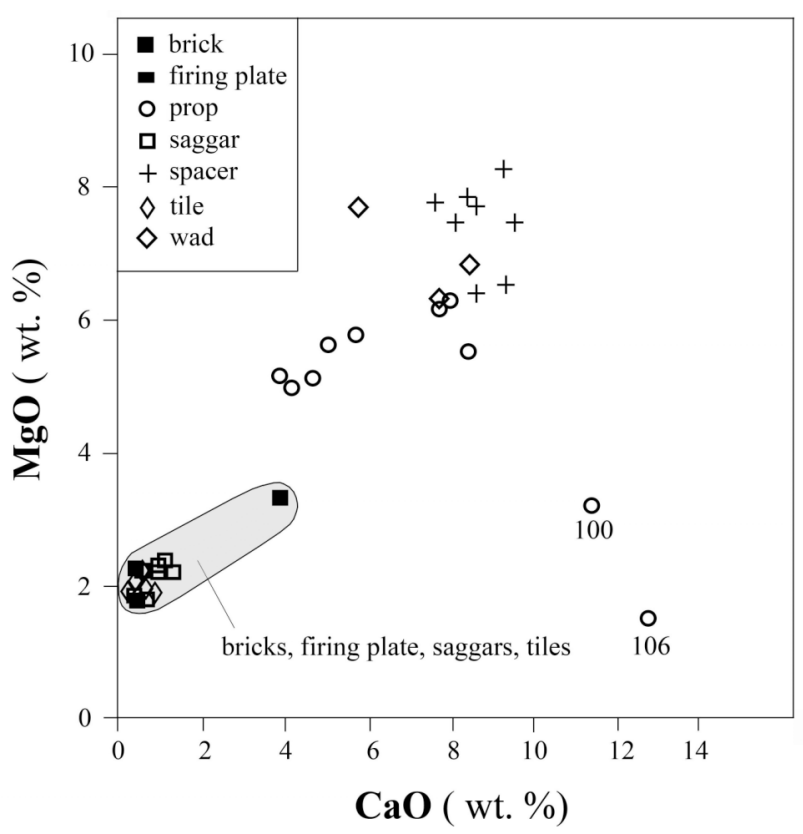

Fig. 3. $\mathrm{MgO}$ - $\mathrm{CaO}$ correlation diagram. 


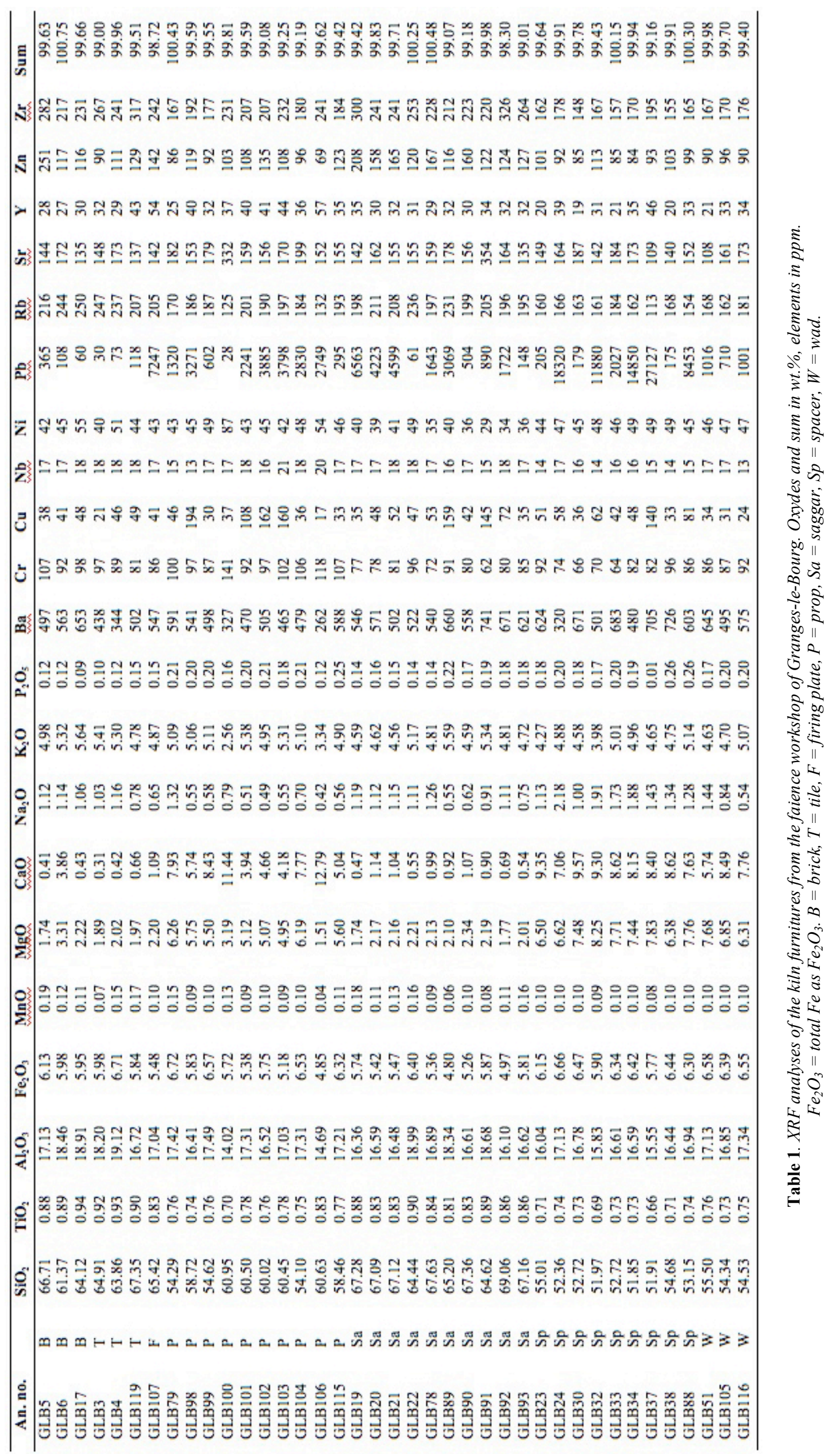




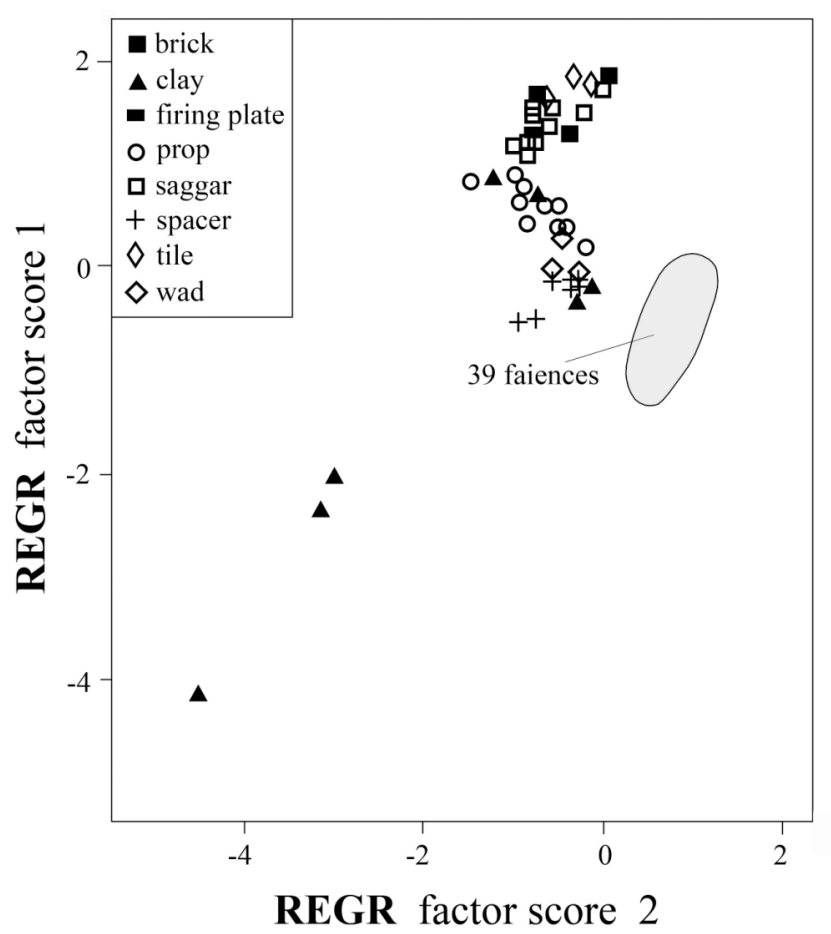

Fig. 4. PCA plot. Compositions of faiences and clays from Maggetti et al. (2009).

\section{DISCUSSIONS AND CONCLUSIONS}

The kiln furniture is chemically inhomogeneous and belong to two groups. The firing plate and all saggars are, like the locally made brick and tiles, $\mathrm{CaO}$ - and $\mathrm{MgO}$-poor. Props, spacers and wads pertain to a second, $\mathrm{CaO}-$ and $\mathrm{MgO}$-rich group and match partially the faience's composition.

The ancient potters obviously used two major recipes: the firing plate \& saggar (= brick \& tile) and the prop \& space recipe. The use of a non-refractory clay for the props and spacers is puzzling. Ceramic objects with such high fluxes will melt around $1100^{\circ} \mathrm{C}$ and are therefore not very well suited to resist the firing temperatures of a furnace kiln, or to support many firing cycles. The potters used local raw materials and not imported, specific Al-rich, refractory clays. For the firing plate and the saggars, decarbonatized top layers of local dolomitic Triassic marls were chosen and mixed with local quartz sands.All spacers, props and wads were made using local dolomitic marls, which were probably not as well processed as the faience paste. A tin opacified glassy coating has been applied on the interior of the firing plate and some saggars. For obvious financial reasons, the potters used significantly less tin oxide, added much more crushed quartz and applied the watery glaze suspension with a much thinner stroke as for the faience. The absence of any significant reaction zone indicates that the glaze suspension was applied on already fired (biscuit fired) plates and saggars.

\section{R E F E R E N C E S}

Contini, D. 2000, Notice explicative de la feuille Lure à 1/50'000e. Éditions du BRGM, Service géologique national, Paris.

Contini, D., Creuzot, J., Dressler, M. \& Théobald, N. 2000, Carte géologique de la France à 1/50'000e feuille 443, Lure. $2^{\text {nd }}$ ed. BRGM, Service géologique national, Paris.

Maggetti, M. 1994, Mineralogical and petrographical metods for the study of ancient pottery. In Proceedings of the $1^{\text {st }}$ European workshop on archaeological ceramics, 1991 (Burragato, F., Grubessi, O. \& Lazzarini, L., Eds.), Università degli Studi La Sapienza, Roma, p. 23-35.

Maggetti, M., Morin, D. \& Serneels, V. 2009, High-Mg faiences from Granges-le-Bourg (Haute Saône, France). In Proceedings of the European Meeting on Ancient Ceramics (EMAC'07) Vessels: inside and outside (Biró, T., Ed.), Hungarian National Museum, Budapest, in print.

Morin, D., Morin-Hamon, H. 2004, La tuilerie-faïencerie de Granges-le-Bourg. Bulletin de la Société d'Histoire et d'Archéologie de l'Arrondissement de Lure (SHAARL), 23: 94-104. 